\title{
The Coronavirus Crisis. Governance, Social and Political Economy Issues (A Short Note)
}

\section{Daniel Linotte* \\ PhD, St Antony's College, UK}

Submission: March 20, 2020; Published: May 21, 2020

"Corresponding author: Daniel Linotte, PhD, St Antony's College, Oxford, UK

Keywords: Coronavirus crisis; Economic structures; Political-administrative; Covid-19; Pandemics; Epidemics

\section{Introduction}

Within just three months, the coronavirus crisis has hit all continents with, after China, Europe becoming the new center of propagation. As indicated by Figure 1, in the Annex, the number of deaths is spiraling - virtually out of control. The US is affected. Africa and Latin American countries are lagging behind. In this note, three critical issues, related to the on-going crisis, are discussed. In the first section, the seemingly lack of crisis management with adequate forecasting tools is discussed. The next section concentrates on the social dimensions of health when pandemics prevail. The influence of the big pharmaceutical companies and major countries is briefly presented in the third section.

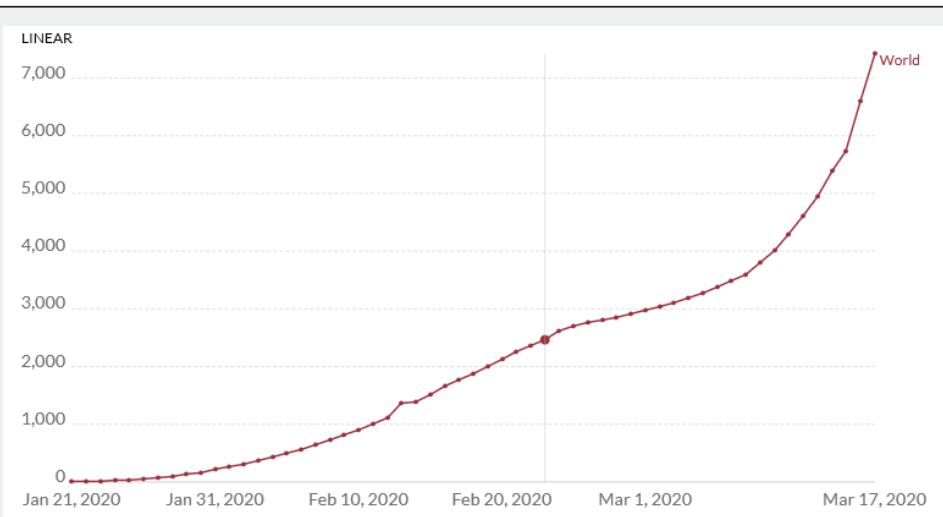

Figure 1: COVID-19 and Deaths (Total World Figures).

Roser et al. [4] (updated on a regular basis).

\section{Tools for Assessing Risks}

\section{The role of think tanks}

The RAND Corporation, a leading US think tank, has developed a number of tools to analyze and prepare for crisis management, including public health emergencies. Considering COVID-19, one of the most recent works produced by the RAND Corporation is the contribution of a multidisciplinary team, involving a mathematician, an information scientist and a physician policy researcher, to assess the evolution of fatality rates [1]. The authors conclude that good estimates of fatality rates can hardly be calculated before the full termination of the pandemic. This work is 
important and raises key-questions about the forecasting models that can be used and the seemingly limited reference to such tools by authorities, at least at the very beginning of the crisis.

\section{Forecasting models}

Even when major pandemic waves end, as shown by a systematic review of studies on the global spread of diseases, there are modelling challenges, related to the quality of data and other factors. Despite problems, findings are interesting. Relying on a well-structured and transparent scoping approach and a series of key-words, three scholars selected 78 studies [2]. They underline the variety of sources and modelling perspectives including deterministic mathematical models and so-called gravity models, developed by economists to explain trade flows between countries. Most interestingly, they report that, with globalization, models confirm that travels contribute significantly to the spread of diseases. Even if the validation of models remains a difficult exercise, such findings could have been a source of inspiration for governments (and WHO also perhaps), especially following the alarming information that flew from China at the very end of 2019. The compulsory quarantine of all travelers coming from China could have been imposed very early - considering actual developments and measures adopted in Europe and the US, it would have represented a low-cost option indeed.

\section{Exponential trends and the benefits of early action}

Even without the use of advanced and complex mathematical and statistical tools developed for simulation and forecasting exercises, when drawing simple graphs based on reported cases of contamination, the exponential nature of the spread of coronavirus could have been detected early, within the five to ten days that followed the very first cases, and interpreted as a serious warning about what may happen when countermeasures are not quickly adopted and effectively implemented. As shown by Figure 2 , early action may help contain, or at least slow down, the spread of the virus and save thousands of lives [3].

Figure 2: The Benefits of Early Action.

Roberts [3].

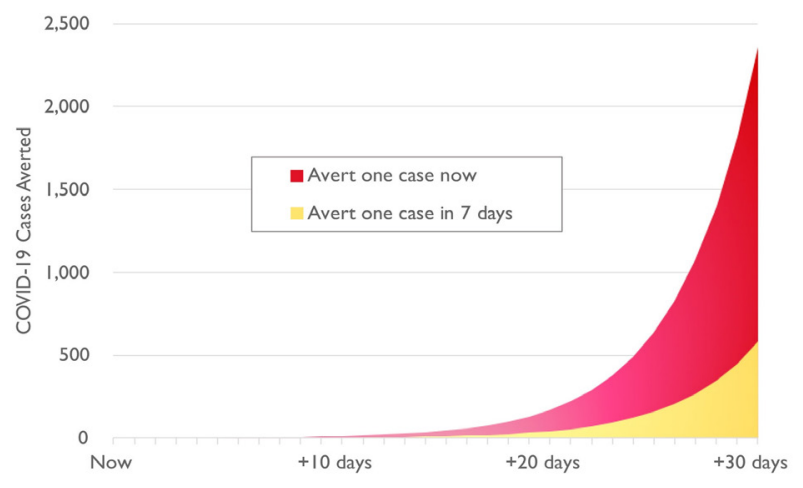

Considering France, it takes about 3 days for the number of cases to double [4]. It implies that, left alone, without public and private initiatives, the virus could potentially hit at least half the population within 2.5 months. Such an extreme scenario would mean that the national health system cannot anymore provide adequate cares to people in need, especially the most vulnerable (ageing population and people with underlying conditions). It could virtually collapse, especially if a significant proportion of the medical staff is contaminated, which is not impossible when resources and protective material are lacking, and healthcare professionals are working long hours under stressful conditions. In fact, it is foreseen that the Italian scenario could happen in other countries [5]. In such a context, wealth, incomes and status in political-administrative and economic structures will matter a lot for effective access to health care services in well-equipped private and public clinics and survival - this is especially true in the countries that are or will be adopting the so-called unethical and risky 'herd immunity' strategy [6].

\section{Social Dimensions}

\section{Poverty and epidemics}

When epidemics occur, they have different impacts on people. The poor people are generally the most impacted by the outbreaks. Poverty explains vulnerability because of low education, detrimental habits, the living environment, low incomes and lack of access to health cares. In the case of Norway, which is a high per capita income country, and despite inclusion policies and generous safety nets, there are still vulnerable groups when pandemics occur - they include people with complex social and/ or health needs, and people with low education and incomes [7]. 
Similar findings are reported for other developed countries. In the US, the black African and the Hispanic/Latino minorities are seen as the most vulnerable minorities.

\section{Coronavirus and the elites}

The spread of coronavirus outside China is associated with international travels, which contributed to its rapid expansion in Europe. Travelers are generally not perceived as poor people. They seem to be business people, traders, international civil servants and tourists that do not belong to the poorest strata of the society - extensive information is perhaps needed to be more conclusive about these travelers. Considering the richest people, with coronavirus, the use of private jets is booming, which allows to avoid contacts with people in crowded airports and escape from risky urban areas to large and safe properties in remote places (countryside, islands, mountains). New Zealand is a favorite destination for Silicon Valley billionaires [8]. Moreover, they can hire 24/7 services of private MD's, with adequate medical equipment. In some cases, luxury nuclear shelters filled with food reserves could also be used for the sake of complete isolation from the rest of the world. Some billionaires became very rich with globalization, which is also associated with the rapid spread of the virus - largely because of travelling and the lower costs of transportation. However, it is worth noting that wealth inequalities have decreased because of the coronavirus - it is estimated that $\$ 6$ trillion were lost with the collapse of global stocks within a few days, in March 2020 [9], which should not prevent the major stockholders to benefit from quality health cares.

\section{Disparities in the EU}

The availability of intensive cares bed in the EU is dispersed in addition to ventilators, such a factor may play a key role when saving the lives of severely infected people [10]. Germany has the highest score, with about 120 beds for 100,000 inhabitants. It is followed by Luxemburg - an EU major fiscal haven - and Romania, a former socialist country. The Scandinavian countries, that are renowned for their safety nets and enjoy high incomes per capita, do not appear at the top of the list. UK, a former EU member, is located below the EU average. Figures about health infrastructures should be considered for further analysis to explain how it can be related to health policies, past strategic decisions and, above all, successful outcomes and failures in the on-going campaign against the coronavirus.

\section{Developing countries}

The spread of Coronavirus beyond China, Europe and the US is taking place and reaching the developing world, in Africa, Asia and Latin America. Most of the poor people live in developing countries, and their fate may worsen because of coronavirus. A large number of precarious and impoverished people work in the informal sector, they can hardly benefit from safety nets and have limited access to health services - when severely ill, little will be done to assist them. They have to continue to work to pay for food and modest shelters and, as a result, they can hardly be quarantined. In addition, the demand for their goods and services is expected to contract, which will worsen their material conditions. According to recent forecasts, the world economy is expected to shrink by more than $\$ 2$ trillion (see Figure 3 ), which will impact on developing countries, reducing further their capacity to address the new situation [11]. Furthermore, even if more aid is being planned to help them, the full mobilization and saturation of health systems in the developed economies could imply that medical aid provided by the rich countries to the poor ones may lack both human and material resources. Also, access to new vaccines that are going to be developed may be rendered difficult because of the lobbying of the large pharma companies, defending their intellectual property rights and market niches, the permanent quest for market dominance, the prohibition of drugs exports by key-countries (India...), and the possible nationalization or, at least, the imposition of state controls on drugs industries [12]. Considering African countries, there is high awareness and some governments seem to take adequate preventive measures on time, with the use of medias and strict controls in airports. In that context, the WHO must also occupy a central position to defend the interests of the developing and poorest countries and secure their access to proper medications and vaccines - it could imply that WHO will be confronted with extreme pressures from the most influential pharma companies and rich countries, which is most likely when the organization is facing funding problems [13].

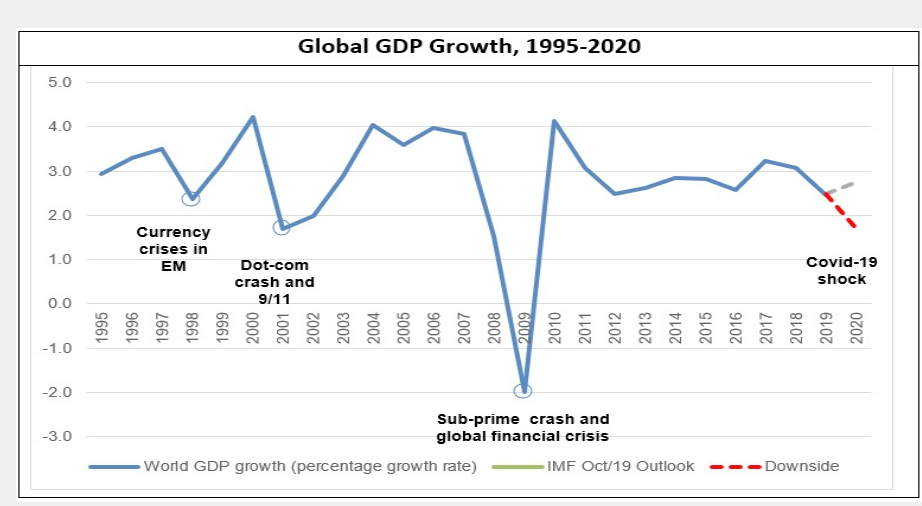

Figure 3: Global GDP Growth, 1995-2020. UNCTAD [11]. 


\section{Pharma Companies and Power Games}

\section{Intellectual property rights}

Pharmaceutical companies invest a lot to develop new drugs in a risky environment characterized by complex practices and competition. The protection of their intellectual property rights is well addressed within the frameworks of the WTO and WIPO. Some OECD countries are willing to go beyond existing agreements and offer more protection to their multinational companies when they negotiate free trade agreements with developing countries, where local producers are eager to develop their own generic drugs, copying expiring rights, which raises sensitive questions in terms of social justice and profits. Access to drugs is also perceived as a critical ethical issue for the low-income people in developed and developing countries.

When epidemics prevail, social justice and human rights perspectives become more acute. In difficult contexts, dialogs between governments, international organizations and companies become critical. Emergencies could justify the use of coercive measures, limited in times, and with compensations perhaps when companies are confronted with significant losses. Direct aid to promising pharma SME's could also be considered, assuming they promote ethical attitudes and social responsibility. In that respect, research works on ethical dilemmas may help understand the factors that explain empathy and generosity [14].

\section{Lobbying and recent developments}

In the US, and other countries also, with what President Eisenhower named the military-industrial complex, the large pharma companies represent powerful lobbies. According to McGreal [15], they may even contribute to health crises, causing thousands of victims - and the coronavirus offers unique new opportunities for gaining more profits, with lobbying and racing [16]. Transparency is becoming a critical issue and civil society should play a major role to identify, report and address abuses, putting pressures on political leaders and lawmakers, to avoid the repetition of 'business as usual'. In the US, such issues have been already raised by politicians.

\section{Controlling the vaccines}

Lobbying does mean unique strong ties between those who are elected and the pharma industry - strategic alliances may forge, with long term implications on market shares and profits, access to appropriate medications and the health conditions of the people, in all countries. Such critical implications may explain the permanent quest for global dominance, with the acquisition of firms that have unique expertise and strong potential. These comments can be illustrated by the recent (and failed) US attempt to pay 1 billion USD to acquire a leading lab in Germany that has the capacity to develop a new vaccine [17].

\section{Final Remarks}

The coronavirus crisis raises sensitive questions related to the quality of governance in countries that are seen as models. As illustrated by the work of the RAND corporation, crisis management requires the mobilization of multidisciplinary teams and the use of specific tools, especially for forecasting. What is also surprising is the seemingly lack of strict protocols when the very early signs were detected. Moreover, despite the evidence and access to key-information, in the EU at least, the political leaders of major countries were still hesitant and, for unclear reasons, delayed the imposition of strict measures that could have saved thousands of lives. The final impacts on individuals will have to be analyzed to better understand the importance of social conditions for survival, in developed and developing countries. The lobbying activities of the big pharma companies and the role of powerful states to gain more dominance must be followed and assessed carefully, from ethical and economic perspectives. The future role of WHO must also be clarified to provide better guidance and support coordination between countries - which may require adequate means and more independence.

\section{Additional Comments - Fighting Covid-19}

\section{Paul Jacques Lamotte ${ }^{1}$}

Daniel Linotte's ${ }^{2}$ note focuses on economic and social issues. The following comments reflects the views of a MD, with a long experience in countries that have been confronted with severe pandemics.

${ }^{1}$ Paul-Jacques Lamotte is a pediatrician, with expertise in the field of tropical medicine and public health. He was involved in technical assistance projects in DRC, Ivory Coast and Senegal. He is the author of a practical guide on Tropical Pediatrics (Kärger Editions, Basel - five editions, in English, French and Spanish). He was involved in many meetings, at European levels and the WHO. Presently, he is volunteering and supporting projects to strengthen health services focusing on children in African countries that have been confronted with severe conflicts (MSV-AZV-DWH: Doctors without Holidays).

${ }^{2}$ Daniel Linotte earned his PhD's from Oxford and Fribourg Universities and held professorship positions in the US (Boston University), Russia (Higher School of Economics) and the EU (Catholic University Leuven, European Institute of Public Administration - EIPA). He drafted the OSCE (Organization for Security and Cooperation in Europe) Strategy Document to address threats stemming from economic and environmental factors, referring, among other things, to health conditions. Based on the Strategy Document, with Patrick Meier, he developed an early warning system that was discussed within the UN system. He contributed to the preparation of a major OSCE event, initiated by the Ministry of Foreign Affairs of France, on the conversion of defense industries in the former socialist countries of central and eastern Europe and corresponding peace dividends. He is presently involved in international projects to support institutional development and capacity building in developing and transition countries, with a focus on trade policy and the implications of globalization. In 2008, he became member of St. Antony's College, University of Oxford (UK). 
A number of drugs and products are being tested, including chloroquine-based ones, for preventing COVID-19 infection and curing patients. Without convincing evidence, with rigorous testing and official validation, the use of specific drugs must be restricted or even prohibited. In that context, it is worth noting that the Belgian government officially informed to refrain prescribing hydroxychloroquine to prevent contamination or cure patients not in hospitals. When patients are using the medication, they must be carefully monitored. Strategic stocks of hydroxychloroquine and chloroquine are being built to be made available when needed and if validated. Considering hospitals, the following recommendations are being made [Sciensano website, March 16, 2020]: "At the time being, the use of investigational or off label medicinal products to treat patients suspected or confirmed COVID-19 should be restricted to hospital use." In addition, "chloroquine has good in vitro activity against SARS-CoV-2 and seems to reduce the duration of viral shedding. This does not mean that this will be translated in clinical efficacy (many previous experiences were disappointing). Results of ongoing clinical trials are eagerly awaited. This drug has been used for decades (at a total of $25 \mathrm{mg} / \mathrm{kg}$ within 3 days) for malaria treatment without any monitoring and side effects, including in pregnant women. However, the therapeutic window is quite narrow (cardiotoxicity/arrhythmia), requiring caution for use at higher cumulative dosages. For this reason, we strongly recommend that its use in suspected/confirmed COVID-19 be restricted to hospitalized patients".

Recent information (see https://epidemio.wiv-isp. be/ID/Pages/2019-nCoV_procedures.aspx) suggests that hydroxychloroquine is more potent than chloroquine in vitro, so that lower dosages (than initially recommended) could be used. This option has been preferred since therapy will be required mostly in older patients and/or in case of severe disease. Since the availability of hydroxychloroquine in sufficient quantity might become a problem, instructions for the chloroquine use will be provided, but caution will be required.

From a more political perspective, it is worth mentioning that, in China, the MD who reported the very first pieces of info about the virus was silenced by the authorities and also died. However, after the initial repressive reactions and delay, the Chinese authorities finally reacted firmly and, considering the sharp fall of new cases and reported deaths, they seem to be able to contain the spread of the virus in the country.

\section{References}

1. Vardavas R, Gidengil CA, Nowak SA (2020) Estimates of COVID-19's Fatality Rate Might Change. And Then Change Again.

2. Walters CE, Mesléb MMI, Halla IM (2018) Modelling the global spread of diseases: A review of current practice and capability. Epidemics 25 $1-8$

3. Roberts S (2020) The Exponential Power of Now. The New York Times.

4. Roser M, Ritchie H, Ospina EO (2020) Coronavirus Disease (COVID-19) - Research and Statistics, Our World and Data website.

5. Morris L, Booth W (2020) Coronavirus curve shows much of Europe could face Italy-like surge within weeks. The Washington Post.

6. Ferguson (2020) The UK is scrambling to correct its coronavirus strategy. MIT Technology Review.

7. Mamelund SE (2017) Social inequality - a forgotten factor in pandemic influenza preparedness. Tidsskriftet Den Norkse Legeforening.

8. Helmore E (2020) Coronavirus lifestyles of the rich and famous: how the $1 \%$ are coping. The Guardian.

9. Phelan J (2020) The coronavirus has reduced wealth inequality by making the rich less rich. Center of the American Experiment.

10. Rhodes A, Ferdinande P, Flaatten H, Guidet B, Metnitz PG, et al. (2012) The variability of critical care bed numbers in Europe. Intensive Care Med 38(10): 1647-1653.

11. UNCTAD (2020) Coronavirus: Can policymakers avert a trillion-dollar crisis?

12. Branswell H (2020) As coronavirus pandemic worsens, health officials fear nationalization of drugs and supplies.

13. Reddy S, Mazhar S, Lencucha R (2018) The financial sustainability of the World Health Organization and the political economy of global health governance: a review of funding proposals. Global Health 14: 119

14. Greene JD, Sommervilla RB, Nystrom LE, Darley JM, Cohen JD (2001) An fMRI Investigation of Emotional Engagement in Moral Judgment. Science 293(5537): 2105-2108

15. McGreal C (2017) How big pharma's money - and its politicians - feed the US opioid crisis. The Guardian.

16. Lerner S (2020) Big Pharma Prepares to Profit from the Coronavirus. The Intercept.

17. The Guardian Staff and agencies (2020) Coronavirus: anger in Germany at report Trump seeking exclusive vaccine deal. The Guardian.

DOI: 10.19080/ASM.2020.05.555660

\section{Your next submission with Juniper Publishers will reach you the below assets}

- Quality Editorial service

- Swift Peer Review

- Reprints availability

- E-prints Service

- Manuscript Podcast for convenient understanding

- Global attainment for your research

- Manuscript accessibility in different formats ( Pdf, E-pub, Full Text, Audio)

- Unceasing customer service

Track the below URL for one-step submission https://juniperpublishers.com/online-submission.php 